\title{
Pengaruh Persentase Serat Pinang terhadap Sifat Mekanik dan Biodegradabilitas Komposit Polipropilena dengan Penambahan Pati Pisang
}

\author{
Mila Putri Artika , Alimin Mahyudin ${ }^{* *}$ \\ Laboratorium Fisika Material, Jurusan Fisika \\ Fakultas Matematika dan Ilmu Pengetahuan Alam Universitas Andalas \\ Kampus Unand Limau Manis, Padang, 25163 Indonesia \\ *milaartika97@gmail.com, *aliminmahyudin23@gmail.com
}

\begin{abstract}
ABSTRAK
Telah dilakukan penelitian mengenai pengaruh persentase serat pinang terhadap sifat mekanik dan biodegradabilitas komposit polimer dengan penambahan pati pisang. Metode yang digunakan pada penelitian ini metode blend dan hand lay-up. Variasi Persentase serat 0\%, 3\%, 5\%, 7\%, dan 9\%. Panjang serat yaitu 3,5 mm. Nilai kuat tarik tertinggi pada sampel dengan persentase serat $3 \%$ yaitu 20,69 MPa. Modulus elastisitas tertinggi diperoleh pada persentase serat $5 \%$ yaitu 489,93 MPa. Nilai regangan dan kuat impak tertinggi pada persentase serat $9 \%$ dan $7 \%$ yaitu $5,6 \%$ dan $0,072 \mathrm{~J} / \mathrm{mm}^{2}$. Nilai biodegradabilitas rata-rata sebesar $0,0028 \%$. Semakin banyak serat maka komposit makin mudah terbiodegradasi. Pada uji mekanik belum didapat persentase serat optimum karena setiap pengujian diperoleh nilai optimum berbeda. Pada uji spektrum FTIR diperoleh informasi terbentuknya ikatan baru. Dari penelitian diperoleh bahwa nilai fraksi volume kritis terdapat pada persentase 5\% dan 7\%.

Kata kunci: serat pinang, polipropilena, pati pisang, kuat tarik, kuat impak, biodegradasi.
\end{abstract}

\section{ABSTRACT}

Research had been conducted to find the effect of areca fiber percentge on mechanical and biodegrability of polimer composites by adding banana starch. The method used in this study is blend and hand lay up. Variation of fiber percentage are 0\%,3\%, 5\%,7\% and 9\% whit fiber length 3,5 mm. The highest tensile strength of value of sample with $3 \%$ fiber pecentage is $20.69 \mathrm{MPa}$. The highest elastic modulus obtained at 5\% fiber percentage that is $489.93 \mathrm{MPa}$. The highest tensile and impact strength value obtained for sampel $9 \%$ and $7 \%$ fiber percentage which is $5.6 \%$ and $0.072 \mathrm{~J} / \mathrm{mm}$. The average biodegrability value is $0.0028 \%$. Using more fiber make composite easily to biodegradable. In the mechanical test, the optimum fiber percentage has not been obtained because every single in this research have a different optimum values. FTIR spectrum shows that the formation new bonds. From the research it was found that the value of the critical volume fraction was at the percentage of 5\% and $7 \%$. Keywords: areca fiber, polipropilene, banana starch, tensile strength, impact strength, biodegradation.

\section{PENDAHULUAN}

Plastik merupakan salah satu bahan polimer yang memiliki peran penting dalam memenuhi kebutuhan manusia, hal ini dikarenakan plastik memiliki keunggulan dibandingkan dengan bahan polimer lain diantaranya lebih ringan, kuat, transparan, tahan air, murah. Meningkatnya kebutuhan plastik mengakibatkan peningkatan jumlah limbah plastik. Sampah plastik merupakan produk polimer sintesis yang tidak dapat terdegradasi secara ilmiah oleh mikroba. Agar proses biodegradasi terhadap polimer bisa terjadi maka dilakukan penambahan pati dan serat, serat yang digunakan yaitu serat pinang.

Serat pinang merupakan salah satu serat alam dalam pembuatan komposit yang pemanfaatannya masih dikembangkan karena belum terlalu banyak komposit yang menggunakan serat pinang. Serat pinang mudah didapat, murah.

Telah banyak dilakukan penelitian mengenai komposit polimer, Kamagi (2017) telah menguji kekuatan mekanik dari serat buah pinang menggunakan matriks epoksi dengan variasi persentase volume serat $3 \%, 5 \%, 7 \%$, dan $9 \%$ dengan panjang serat $3,5 \mathrm{~cm}$. Hasil pengujian tarik menunjukan kekuatan tarik rata-rata terbesar terdapat pada komposit dengan volume serat $3 \%$ dengan nilai $5,614 \mathrm{~kg} / \mathrm{mm}^{2}$ atau $40,705 \mathrm{MPa}$ dan yang terkecil pada volume $7 \%$ dengan nilai $3,636 \mathrm{~kg} / \mathrm{mm}^{2}$. Regangan rata-rata terbesar terdapat pada komposit dengan volume serat $3 \%$ dengan nilai $2,48 \%$ dan yang terkecil pada presentasi volume $7 \%$ dengan nilai $2,0 \%$. Nilai modulus elastisitas rata-rata terbesar terdapat pada komposit berpenguat serat pinang $7 \%$ dengan nilai 18,265 MPa dan terkecil pada komposit berpenguat serat pinang 9\% dengan nilai 
14,548 MPa jika dibandingkan dengan komposit berpenguat serat pinang dengan fraksi volume lainnya.

Hidayat (2015) telah melakukan penelitian tentang pengaruh penambahan pati talas terhadap sifat mekanik dan degradabilitas plastik campuran polipropilena dan gula jagung. Pada penelitian ini, pati talas ditambahkan sebanyak 0 g, 9 g, 12 g, 15 g, dan 18 g. Nilai kuat lentur dan tarik tertinggi diperoleh dari sampel dengan penambahan pati talas $9 \mathrm{~g}$, yaitu 37,44 N/mm dan $5,19 \mathrm{~N} / \mathrm{mm}$. Sampel yang paling cepat terdegradasi adalah sampel dengan penambahan pati talas sebanyak $18 \mathrm{~g}$, dengan laju degradasi rata-rata $0,68 \%$ per hari.

Dari penelitian- penelitian tersebut, maka akan dilakukan penelitian lebih lanjut menegenai pengaruh persentase serat pinang terhadap sifat mekanik dan biodegradabilitas komposit polipropilena dengan penambahan pati pisang".

\section{METODE}

Pengujian biodegradasi dilaksanakan di Laboratorium Fisika Material Jurusan Fisika, FMIPA Unand. Pengujian kuat tarik dan kuat impak dilakukan di Laboratorium Mekanik Politeknik Negeri Padang. Pengujian FTIR dilakukan di Laboratorium Jurusan Kimia Universitas Negeri Padang. Teknik penelitian yang digunakan adalah metode blend dan hand lay up.

\subsection{Persiapan dan Pembuatan Spesimen}

Serat pinang dijemur sampai kering di bawah sinar matahari selama 2 hari. Pengolahan serat pinang dilakukan secara tradisional meliputi pemisahan dan perendaman serat. Serat direndam dengan larutan alkali $\mathrm{NaOH} 5 \%$ selama 2 jam. Setelah direndam serat pinang dibilas dengan air untuk menghilangkan kandungan $\mathrm{NaOH}$ yang tersisa lalu serat sabut pinang dikeringkan dengan oven bersuhu lebih kurang $140{ }^{\circ} \mathrm{C}$ selama 2 jam untuk meghilangkan kadar air yang tersisa. Selanjutnya serat sabut pinang dipotong sepanjang $3,5 \mathrm{~mm}$.

Resin polipropilena dicairkan menggunakan hot plate dengan suhu $300{ }^{\circ} \mathrm{C}$ selama 30 menit, sehingga plastik polipropilena bekas tersebut mencair. Selanjutnya resin yang telah mencair dicampurkan dengan pati pisang dan serat dan diaduk hingga merata. Campuran resin dituang ke dalam cetakan dengan ukuran $16,5 \mathrm{~cm} \times 2 \mathrm{~cm} \times 0,5 \mathrm{~cm}$ untuk uji kuat tarik, ukuran 5 $\mathrm{cm} \times 5 \mathrm{~cm} \times 0,5 \mathrm{~cm}$ untuk uji biodegradasi dan $5,5 \mathrm{~cm} \times 1 \mathrm{~cm} \times 1 \mathrm{~cm}$ untuk uji FTIR, SEM, uji impak. Kemudian dilakukan pemecahan gelembung udara pada resin dengan menggunakan ujung spatula hingga gelembung tersebut berkurang, sampel yang masih bisa dibentuk kemudian diberi pemberat dari besi di atas magnetik stirer hingga semua permukaan rata. Komposit ditunggu sampai benar-benar kering. Proses pengeringan maksimal membutuhkan waktu sekitar 5 menit. Setelah komposit kering kemudian komposit dilepaskan dari cetakan dan siap untuk diuji.

\subsection{Pengujian dan Pengambilan Data}

\subsubsection{Uji mekanik}

Uji kuat tarik merupakan salah satu uji stress-strain mekanik yang bertujuan untuk mengetahui kekuatan bahan terhadap gaya tarik. Pengukuran kuat tarik dirumuskan seperti persamaan:

$$
\sigma=\frac{F}{A}
$$

dengan $\sigma$ adalah kuat tarik $\left(\mathrm{kg} / \mathrm{cm}^{2}\right), F$ adalah gaya tarik tegak lurus terhadap permukaan $(\mathrm{N})$, dan $A$ adalah luas bidang spesimen yang ditarik $\left(\mathrm{cm}^{2}\right)$.

Regangan atau strain adalah perubahan pada ukuran benda karena gaya dalam kesetimbangan dibandingkan dengan ukuran semula. Regangan dapat dihitung dengan menggunakan persamaan:

$$
\varepsilon=\frac{\Delta l}{l}
$$


dengan $\varepsilon$ adalah regangan, $\Delta l$ adalah perubahan panjang spesimen $(\mathrm{cm})$, dan $l$ adalah panjang awal spesimen $(\mathrm{cm})$.

Modulus elastisitas adalah perbandingan antara tegangan dan regangan. Modulus elastisitas didapatkan menggunakan persamaan:

$$
E=\frac{\sigma}{\varepsilon}
$$

dengan $E$ adalah modulus elastisitas $\left(\mathrm{kg} / \mathrm{cm}^{2}\right)$.

\subsubsection{Kuat Impak}

Uji impak adalah jenis pengujian yang dilakukan untuk mengetahui seberapa besar kekuatan material tersebut. Nilai harga impak dapat dihitung menggunakan persamaan:

$$
H I=\frac{E}{A}
$$

dengan $H I$ adalah harga impak $\left(\mathrm{J} / \mathrm{mm}^{2}\right), E$ adalah energi serap impak $(\mathrm{J})$, dan $A$ adalah luas penampang $\left(\mathrm{mm}^{2}\right)$.

\subsubsection{Biodegradasi}

Metode kuantitatif yang paling sederhana untuk menguji terjadinya biodegradasi suatu polimer adalah dengan menentukan kehilangan massa dan degradabilitas material polimer. Persentase kehilangan massa dapat ditentukan dengan persamaan:

$$
\% \text { massa }=\frac{m_{i}-m_{f}}{m_{i}} \times 100 \%
$$

dengan $m_{i}$ adalah massa spesimen sebelum proses biodegradasi $(\mathrm{g})$ dan $m_{f}$ adalah massa spesimen sesudah proses biodegradasi $(\mathrm{g})$.

Degradabilitas suatu materi dapat ditentukan dengan melihat hasil persen massa yang diperoleh dalam selang waktu tertentu. Secara matematis degradabilitas dapat dilihat pada persamaan:

$$
\text { Degradasi }=\frac{\text { \%massa }}{\text { waktu }}
$$

\section{HASIL DAN DISKUSI}

\subsection{Kuat Tarik}

Pada penelitian ini, uji kuat tarik dilakukan untuk mengetahui seberapa besar pengaruh fraksi massa dan orientasi serat terhadap kekuatan tarik, regangan, dan modulus elastisitas yang dimiliki oleh masing-masing spesimen uji. Berdasarkan hasil pengujian dan perhitungan didapat data seperti pada Gambar 1.

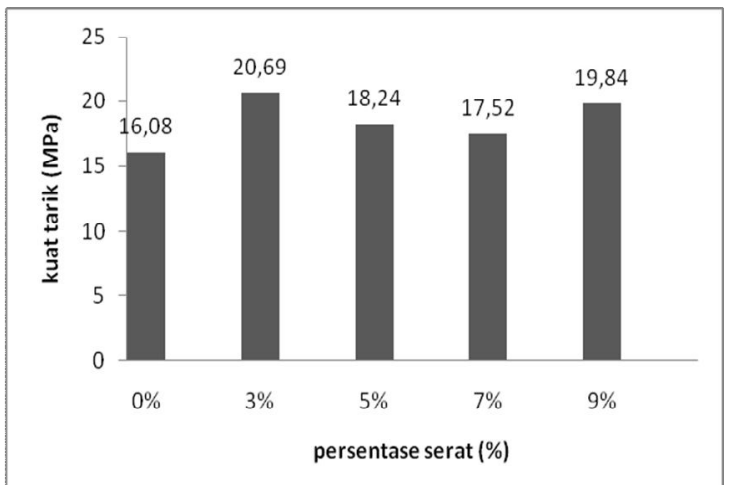

Gambar 1 Pengaruh persentase serat terhadap kuat tarik resin polipropilena dicampur pati pisang 
Berdasarkan Gambar 1 nilai kuat tarik yang didapatkan tidak linear atau mengalami fluktasi terhadap banyaknya serat pada komposit, hal ini disebabkan adanya pengaruh dari perletakan serat yang acak di dalam komposit sehingga orientasi serat dalam komposit menumpuk. Nilai kuat tarik terbaik yang diperoleh pada penambahan serat sebanyak $3 \%$. Nilai kuat tarik tertinggi resin polipropilena dicampur pati pisang didapat pada persentase serat $3 \%$ yaitu 20,96 MPa dan kuat tarik terendah pada persentase serat $0 \%$ yaitu sebesar 16,08 MPa, hal ini bisa disebabkan adanya cacat yang menyebabkan ikatan antaramuka (interface) matriks dan serat kurang baik. Penurunan kuat tarik terjadi karena lemahnya ikatan antar serat pada komposit, lemahnya ikatan serat ini dipengaruhi oleh fraksi volume serat, persentase serat yang terlalu banyak akan membuat orientasi serat pada komposit tidak teratur hingga menghasilkan kekuatan yang lebih rendah. Pada uji kuat tarik ini diperoleh nilai fraksi volume kritis pada persentase $7 \%$.

Nilai regangan dihasilkan dari perbandingan pertambahan panjang spesimen terhadap panjang mula-mula. Berdasarkan hasil dari pengujian dan perhitungan didapat data untuk nilai regangan seperti pada Gambar 2.

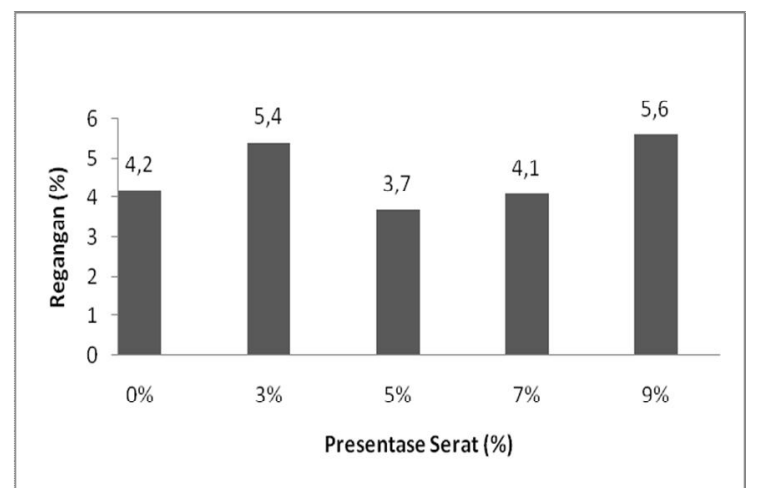

Gambar 2 Pengaruh persentase serat terhadap regangan resin polipropilena dicampur pati pisang

Berdasarkan Gambar 2 dapat dilihat bahwa nilai regangan tertinggi diperoleh dari persentase serat $9 \%$ yaitu sebesar $5,6 \%$ dan yang terendah pada persentase serat $5 \%$ yaitu sebesar 3,7\%. Hal ini menunjukkan bahwa nilai regangan juga dipengaruhi oleh ikatan antara matriks dan serat. Dimana diperoleh fraksi volume kritis pada persentase 5\%.

Dari nilai kuat tarik dan regangan yang didapatkan, maka diperoleh nilai modulus elastisitas. Modulus elastisitas yang didapatkan dari pengaruh persentase serat pinang dapat dilihat pada Gambar 3.

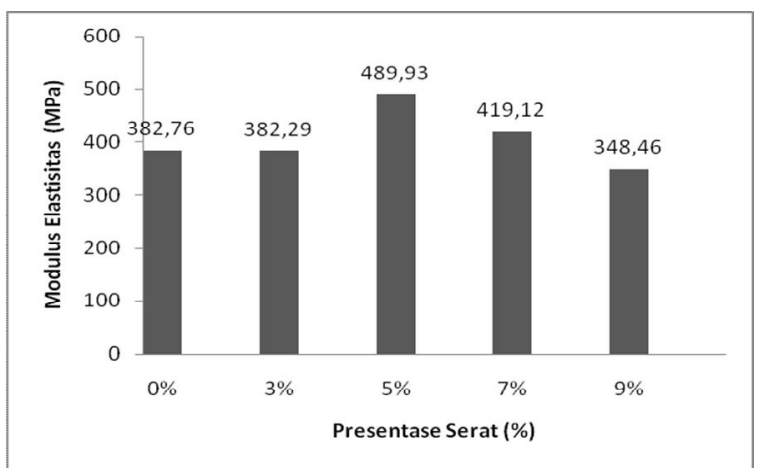

Gambar 3 Pengaruh persentase serat terhadap modulus elastisitas resin polipropilena dicampur pati pisang

Gambar 3 melihatkan bahwa nilai modulus elastisitas tertinggi pada persentase serat $5 \%$ yaitu sebesar 489,93 MPa dan yang terendah pada persentase serat 9\% yaitu sebesar 348,46 MPa. Modulus elastis mengalami penurunan seiring dengan bertambah banyaknya persentase serat yang digunakan.Semakin besar persentase serat yang yang diberikan maka semakin kecil 
nilai modulus elastis yang didapatkan. Berdasarkan nilai modulus elastis yang didapat dikatakan bahwa komposit memiliki kemampuan mempengaruhi nilai tegangan, dimana semakin besar nilai modulus elastis semkin besar juga nilai tegangan yang didapat. Perbandingan antara kuat tarik terhadap regangan yang mana nilai modulus elastisitas berbanding lurus terhadap nilai kuat tarik dan berbanding terbalik terhadap regangan.

\subsection{Kuat Impak}

Uji kuat impak dilakukan untuk mengetahui besarnya energi yang diserap untuk mematahkan spesimen. Dari hasil pengujian didapatkan nilai kuat impak seperti pada Gambar 4.

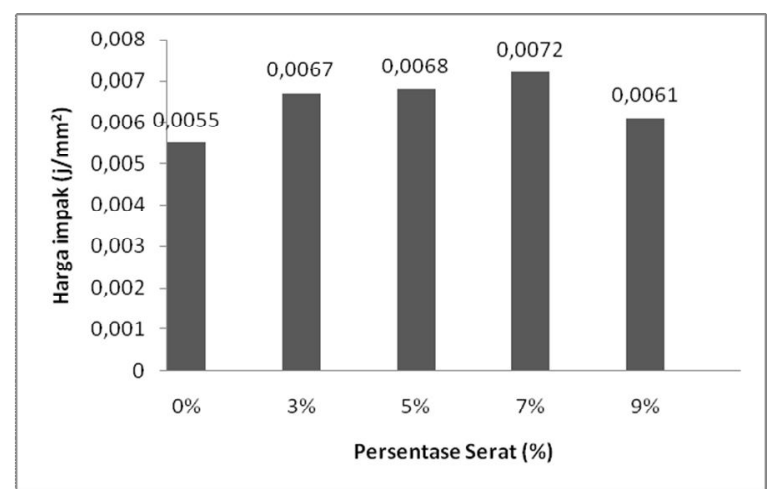

Gambar 4 Pengaruh persentase serat terhadap kuat impak resin polipropilena dicampur pati pisang

Dari Gambar 4 di atas dapat dilihat bahwa panjang serat $9 \mathrm{~mm}$ mempunyai kuat impak yang tertinggi yaitu sebesar $0,0052 \mathrm{~J} / \mathrm{mm}^{2}$ dan panjang serat $15 \mathrm{~mm}$ memiliki nilai kuat impak terendah yaitu sebesar $0,0023 \mathrm{~J} / \mathrm{mm}^{2}$. Perbedaan kuat impak dari variasi panjang serat juga dapat disebabkan oleh beberapa faktor diantaranya gaya adhesi yang rendah sehingga kemampuan komposit untuk menyerap energi yang diberikan menjadi lebih kecil. Adanya penambahan pati pada komposit ini menyebabkan kuat impak lebih baik karena pati yang dicampurkan pada epoksi mampu menyerap energi lebih baik.

\subsection{Biodegradasi}

Pengujian biodegradasi bertujuan untuk menentukan laju perubahan massa spesimen setelah penguburan. Proses degradasi dapat diketahui dengan cara melihat perubahan massa spesimen sebelum dan sesudah penguburan di dalam tanah dalam rentang waktu tertentu. Pada Gambar 5 dapat dilihat nilai degradasi spesimen setelah penguburan selama 30 hari.

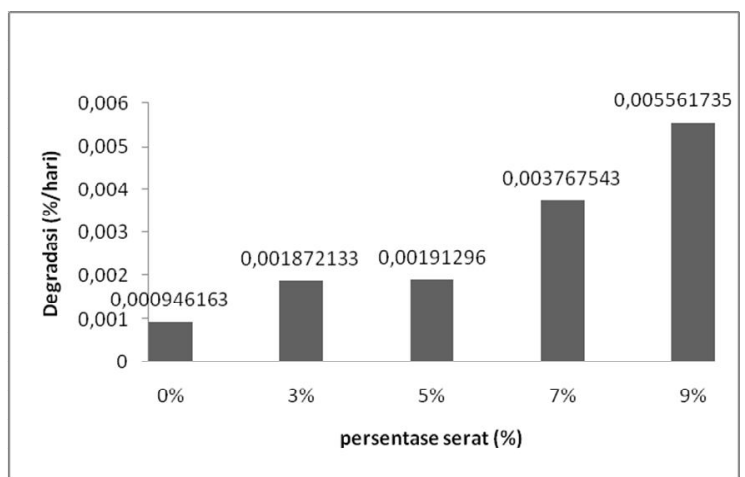

Gambar 5 Pengaruh persentase serat terhadap laju degradasi resin polipropilena dicampur pati pisang

Persentase serat pada uji degradasi berpengaruh dimana semakin banyak serat yang dicampurkan dengan resin polipropilena pada setiap spesimen maka semakin cepat proses degradasi karena serat pinang disukai oleh mikroba. Presentase optimum serat adalah presentase serat $9 \%$. Pati pisang yang dicampurkan pada resin polipropilena juga meningkatkan proses 
degradasi, sehingga spesimen akan mudah terurai. Faktor lain yang sangat berpengaruh terhadap degradasi adalah kelembaban dan banyaknya mikroba pengurai dalam tanah (Firdaus dan Anwar, 2004). Adanya jarak antara sampel selama penguburan mengakibatkan kelembaban dan jumlah mikroba dalam tanah berbeda-beda.

\subsection{Uji FTIR}

Ikatan polipropilena yaitu C-H pada bilangan gelombang $2951,63 \mathrm{~cm}^{-1}, \mathrm{CH}_{3}$ pada bilangan gelombang $1376,28 \mathrm{~cm}^{-1}$ dan $\mathrm{CH}$ alkena pada bilangan gelombang $997,62 \mathrm{~cm}^{-1}$ dan ikatan pada pati pisang adalah $\mathrm{OH}, \mathrm{C}=\mathrm{O}, \mathrm{C}-\mathrm{O}-\mathrm{C}$.

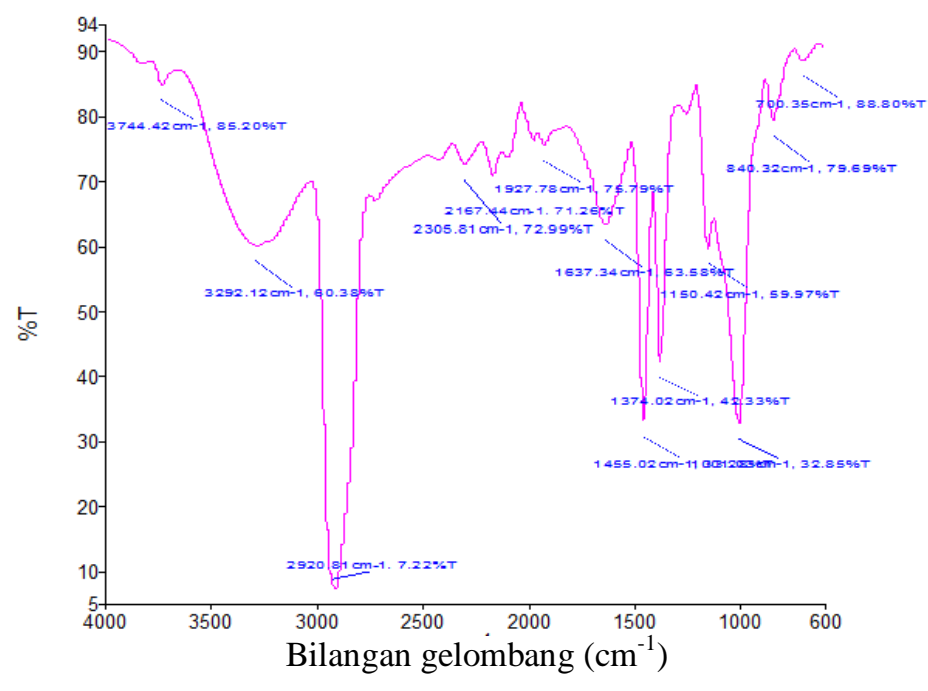

Gambar 6 Hasil spektrum FTIR

Berdasarkan hasil spektrum FTIR pada sampel diperoleh informasi adanya ikatan baru yaitu N-H pada bilangan gelombang $3744,42 \mathrm{~cm}^{-1}, \mathrm{C}=\mathrm{C}$ pada bilangan gelombang $2305,81 \mathrm{~cm}$ ${ }_{1}^{1}, \mathrm{C}=\mathrm{N}$ pada bilangan gelombang $2305,81 \mathrm{~cm}^{-1}, \mathrm{C} \equiv \mathrm{C}$ pada bilangan gelombang $2167,44 \mathrm{~cm}^{-1} \mathrm{dan}$ C-O pada bilangan gelombang $1150,42 \mathrm{~cm}^{-1}$.

\section{KESIMPULAN}

Pada penelitian belum didapatkan persentase serat yang optimum pada pengujian, hal ini dikarenakan nilai kekuatan optimum pada tiap-tiap pengujian terdapat pada persentase serat yang berbeda. Nilai kuat tarik maksimum pada presentase serat $3 \%$ yaitu $20,69 \%$. Nilai modulus elastisitas maksimum pada persentase serat $5 \%$ yaitu 489,93 MPa. Nilai tegangan optimum pada presentase serat $9 \%$ yaitu $5,6 \%$, dan nilai impak maksimum pada presentase serat $7 \%$ yaitu $0,0072 \mathrm{~J} / \mathrm{mm}$. Lama penguburan yaitu 30 hari dengan nilai persen massa $0,084 \%$ dan nilai degradabilitas $0,0028 \%$ / hari. Semakin banyak serat maka komposit makin mudah terbiodegrdasi. Dari penelitian diperoleh bahwa nilai fraksi volume kritis terdapat pada persentase $5 \%$ dan $7 \%$.

\section{DAFTAR PUSTAKA}

Dieter, G.E., Mechanical Metallurgy, Kosaido Printing, Co, Tokyo, 1981.

Firdaus, F., dan Anwar, C., Potensi Limbah Padat-Cair Industri Tepung Tapioka Sebagai Bahan Baku Film Plastik Biodegradabel, Logika, hal. 38-44, Yogyakarta, 2004.

Hidayat, R., Mulyadi, S., dan Handani, S., Pengaruh Penambahan Pati Talas Terhadap Sifat Mekanik dan Sifat Biodegradabel Plastik Campuran Polipropilena dan Gula Jagung, Skripsi, Jurusan Fisika, Universitas Andalas, Padang, 2015.

Kamagi, J. R. F. D., Sifat Komposit Berpenguat Serat Buah Pinang dengan Variasi Fraksi Volume 3\%, 5\%, 7\%, dan 9\%, Skripsi, Jurusan Teknik Mesin, Universitas Sanata Dharma, Yogyakarta, 2017. 